\title{
The Name of God in the Revised Standard Version
}

\author{
ELSDON G. SMITH
}

\section{I}

$\mathrm{N}$ THE Hebrew Old Testament the principal names used for God are three: Elohim, El and Yahveh. Jah, an abbreviation of Yahveh, is also occasionally found. There is much to be learned from a serious study of these names and the way in which they are used.

Elohim is the plural form of the name Eloah. By using the plural form the Jews did not mean to imply that there were many gods. Some have suggested that Elohim referred to the Trinity, Father, Son and Holy Spirit, but the Jews used this form in the first chapter of Genesis and throughout the entire Old Testament. That by Elohim was meant one God is evidenced by the fact that it is used with a singular verb and with singular pronouns. Among the early Hebrews the plural form was used to indicate intensity of some kind, and thus the name in this form denotes extreme reverence. Eloah means 'the worshipped'; Elohim means 'the most worshipped.' Eloah is found only a few times in the Old Testament and then chiefly in the poetical and later books.

$E l$, as a name for God, is not an abbreviation or shortened form of Eloah; its plural is Elim. Among the Semitic peoples $E l$ is found as a common term for God, although it occurs in the Old Testament only 217 times compared to the 2570 times that Elohim is found. As a common noun it is analogous to our term God, but the two words differ in meaning. El signifies 'the might, or power,' while the Anglo-Saxon word God means 'one who is invoked, or to whom sacrifice is offered.'

While both Elohim and $E l$ are used as common nouns for God, and also for pagan gods, the real, personal name of God is the fourlettered Yod He Vav He, the Tetragrammaton of the Hebrews, which is most accurately transliterated to Yahveh. It is found more 
than six thousand times in the Old Testament, not once in the New Testament. This is the name God gave in answer to Moses' request for God's name when He talked with Moses out of the burning bush (Exodus iii, 15). The King James version does not make it very clear.

When God first revealed His sacred name to Moses, He used the form Ehyeh, which is translated to 'I AM.' With the Hebrews the meaning of a name was more important than its form. When God pronounces His name, it is ' $I$ AM'; when others enunciate it, the form is 'He is,' which is Yahveh, although God also used that form later. When God gave His name to Moses, He probably meant it as a symbol that His great promises would be kept, similar to the way we sign our name to a contract to indicate our assent to be bound.

Jehovah is strictly a Christian form of Yahveh, never having been used by the Jews. It was originated in 1270 by mistakenly giving the Tetragrammaton the vowels of Edonai or Adonai, meaning 'Lord.'

The Pentateuch uses both Elohim and Yahveh, while the strong theocratic and historical books relating to Israel, such as Joshua, Judges, Samuel and Kings, use chiefly Yahveh. The Psalms (except Psalms 42 to 84 ) usually employ the name, Yahveh.

To the Jews during the Christian era, Yahveh was such a sacred name that they refrained from pronouncing it except in the Temple. When reading the Old Testament they substituted another word, such as Elohim, Adonai, Tetragrammaton and Lord. Even some of the substituted names, such as Elohim and Adonai, later became so sacred that they ceased using them, or substituted incorrect spellings. In writing they used various symbols in place of the Holy Name, usually one to four yods.

After the captivity the Jews pronounced the Name only once a year, and even then it was pronounced only by the High Priest in the Temple at Jerusalem on Yom Kippur, or Day of Atonement. It was given in a low voice during the chant so that the people listening could not hear it. In the provinces they always used a substituted word. After the destruction of the Temple the "great and terrible name" was never pronounced. Thus the pronunciation was wholly lost, and scholars today can only conjecture as to the correct sound. Most scholars are agreed that Yahveh represents very closely the original sound of the Name. 
The superstitious heathen, always ready to employ the name of any god as a magic name, quickly seized upon the four-lettered name revealed to the Jews. The careful and reverent use of the Name by the Jews, and particularly their refusal to pronounce the Name, convinced the pagans that it was indeed a most potent, magical name. Yahveh became the greatest magical name in the world. A thousand failures to invoke magic by the use of the Name would be ascribed to the inability to pronounce it correctly, while one apparent success would serve to convince them that the Name, exactly pronounced, was the key to godly power.

Ancient peoples among almost all nations firmly believed that there was magic in the names people bore. While the medieval Jews and pagans recognized that gods had power, they also thought that there was creative power in their god's names separate and apart from the powers wielded by the god. Gods were thought, in Egypt and elsewhere, to have created themselves originally by the act of pronouncing their names.

It is unfortunate that the translators of the Revised Standard Version decided to eliminate Yahveh entirely and to use LORD instead. It would seem that a name revealed by God Himself would be of such importance that translators would try to include it in as accurate a form as possible. The translators of the Revised Standard Version did affirm that the Bible was more than a historical document-more than a classic of English literature; they recognized it as a record of God's dealing with men, of God's revelation of Himself and His will. As it is a revelation of God, the revelation of His Name is important.

Those working on the Revised Standard Version announced their decision not to use "Jehovah" as far back as 1938. At that time Dr. Luther A. Weigle was quoted in the newspapers as saying that the change was made because, "Jehovah is not a functioning religious term." He further contended that people never think of praying to Jehovah.

Just what Dr. Weigle meant by saying that Jehovah was not a "functioning religious term," is not clear. If he meant that people did not fully understand the Name, this would scarcely be a reason for not retaining it. If we were to retain in the Bible only that part that was fully understood, we would lose much of that sacred book.

Perhaps Dr. Weigle meant by "functioning religious term" that 
the Name was not used or understood in modern religious worship. Many lay people do understand it, though. And if the Name given directly by God Himself is not a "functioning religious term," it should be. That would be a further reason for retaining the Name and making it crystal clear to students of the Bible. The exact words of God, when we know them, should not be lightly discarded.

That the members of the Committee were not fully satisfied with their decision to discard the name Jehovah, although their decision was unanimous, is, perhaps, emphasized by their full discussion of the problem three different times-in 1930, 1937 and 1951, as reported by Professor George Dahl in the portion he wrote of the Introduction to the Revised Standard Version of the Old Testament.

The Committee recognized the fact that Jehovah was not a correct rendering of the Tetragrammaton. Why didn't they adopt the term Yahveh then? It is not suggested that the form Jehovah should have been retained, although that would be better than dropping the sacred name entirely; Yahveh should have been adopted. Merely because that form was unfamiliar to many lay readers was not a valid reason for discarding it. They altered words in the twenty-third Psalm which many people can recite from memory, and changed many other well-known words in many familiar verses because they regarded the changes as a more accurate translation of the original Scriptures.

Professor Millar Burrows wrote that the Committee accepted seriously the fact that "the belief in divine revelation makes it obligatory to seek only the real meaning of every word and sentence in the Scriptures, and to express just that meaning as exactly and adequately as it can be done in English." LORD is not an English translation of the divine Name; it is merely a word used instead of the sacred term. No attempt was made to translate other personal names in the Old Testament.

Even if it were decided to follow the King James version and substitute the term $L O R D$ in most places, the correct name might well have been retained in enough passages to bring it to the attention of serious readers. A footnote is not sufficient.

In many places in the Old Testament the rendering $L O R D$ is awkward and unsatisfactory. When God replied to Moses' inquiry 
as to His name, saying, "Say this to the people of Israel, "The LORD, the God of your fathers, the God of Abraham, the God of Isaac, and the God of Jacob, has sent me to you'; this is my name for ever, and thus I am to be remembered throughout all generations," (Exodus iii, 15), the statement of the Name is far from clear. The full implications of God's words from the burning bush are difficult enough to comprehend without the concealment of His name. When the Revised Standard Version records Moses and the people of Israel singing, "The LORD is a man of war; the LORD is his name" (Exodus xv, 3), the rendering is unnecessarily awkward. In Psalm lxxxiii, 18, the song ends, "Let them know that thou alone, whose name is the LORD, art the Most High over all the earth," the revealed Name should appear to avoid confusion. Again in Isaiah xlii, 8, the Revised Standard Version has it as "I am the LORD, that is my name"; the reader must stop and remember that $L O R D$, written all in capitals, refers to the sacred Name.

Is it clear to the Bible student when he reads in Exodus vi, 2, 3: "And God said to Moses, 'I am the LORD. I appeared to Abraham, to Isaac, and to Jacob, as God Almighty, but by my name the LORD I did not make myself known to them.' "?

That God regarded His name as an important revelation of Himself to man is clear from the many times he enunciated it. In Exodus xxxiii, 19, God told Moses, "I will make all my goodness pass before you, and will proclaim before you my name 'The LORD'; and I will be gracious to whom I will be gracious, and will show mercy on whom I will show mercy." In Exodus ix, 16, God directed that His name be declared throughout all the earth.

God regarded the proper use of His name as so important that He made it a part of His ten commandments, when He ordered, "You shall not take the name of the LORD your God in vain; for the LORD will not hold him guiltless who takes his name in vain." God did not say that His name was not to be used, only that it was not to be used, "in vain."

That the Name of Yahveh is important in the worship of God is further emphasized by the many times it is mentioned in the Psalms. Indeed, no Biblical scholar will deny the importance of the form Yahveh. To see at a glance the attention the term "name" has been given in the Bible just turn to that word in a concordance. 